\title{
Employee Turn Over Intention: The Roles of Supervisor Leadership Style, Perceived Supervisor Support and Motivation
}

\section{Chandra Setiawati}

Faculty of Economics and Business, Universitas Kristen Satya Wacana, Indonesia

$$
\text { Lieli Suharti }{ }^{1} \text {, }
$$

Faculty of Economics and Business, Universitas Kristen Satya Wacana, Indonesia lieli.suharti@staff.uksw.edu

\begin{abstract}
The supervisor leadership style and the perceived supervisor support toward motivation play an important role in improving employee motivation, the better motivation will also decrease turnover intention. The purpose of this research is to know the influence of supervisor leadership style, the perceived supervisor support toward motivation and its impact on turnover intention. The type this research was a quantitative research. The population of this research was the employees of production division of a Garment company in central Java as many as 1057 employees. The samples were 197 respondents. The data were collected by distributing questionnaires. The analysis technique used was quantitative descriptive statistics by using multiple regression test and simple regression. The result of the research showed that the supervisor leadership style and the supervisor perception toward motivation had positive effect. Finally, motivation was found negatively affecting turnover intention.
\end{abstract}

Keywords: supervisor leadership style; perceived supervisor support; motivation; turnover intention

JEL Classification: J29, J63

\footnotetext{
${ }^{1}$ Corresponding author
} 


\section{INTRODUCTION}

Garment industry is an
industry that processes raw materials into finished material and its production requires a lot of manpower. Nevertheless, the employee turnover rate in the garment industry is relatively high (Sidharta \& Margaretha, 2011). Turnover is not a new concept in the garment company, but it is often a problem that is commonly found in the garment industry, making it interesting.

Employee turnover is usually preceded by an intention to leave (turnover intention). Turnover intention was a desire to leave the company, which could be caused by various reasons and one of them was the desire to get a better job. According to Listiniasih \& Mujiati (2015), the employees' desire to leave the company could affect the employee's behavior at work. Employees become unmotivated at work and do not want to try wholeheartedly at work. Problems arising from intensive turnover could have a negative impact on the company (Gandika \& Franksiska, 2015).

In garment companies, supervisors play an important role because a supervisor will drive and direct employees in achieving the target set by the company. Basically, the inspiring supervisor leadership style and the supervisor support may bring motivation to the subordinates. Based on a previous research, Liliek Tatiyani (2004) found that the superiors' support had a positive effect on employee's motivation to work. This was also supported by a research by Nugraheny (2009) who found that the superiors' support also had a positive effect on employee's motivation to work. Employee's high motivation to work is strongly influenced by the support from both employers and colleagues.

By having a motivation to work, the employee's turnover intention will be lower. Azhar (2009) showed that there was a relationship between leadership style and motivation to work. Riyadi's research (2011) also proved that the supervisor leadership style significantly influenced employee's motivation to work.

The perceived supervisor support (PSS) is the employee's general view of the extent to which supervisors value their commitment and empathize about their wellbeing (Chun Lin, 2015). Perceived supervisor support has some influences on employees. According to Carl et al., (2007), supportive superiors would have a positive impact on employees such as reducing work boredom, enabling employees to tolerate workloads, increasing work motivation, increasing employees' confidence, lowering employees' anxiety, and increasing employees' expectations toward their performance. This was supported by (Curiel, 2004) who stated that the high support shown by the supervisors of the company was able to provide high motivation for employees to work better.

There are several studies showing the differences in the influence between supervisor leadership styles on turnover 
intention. A research conducted by Choi et al., (2012) dan Paaisal et al., (2018) showed that supervisor leadership influenced turnover intention, whereas a research conducted by Jandu (2015) showed negative influence and its significance of the leadership style toward turnover intention. Furthermore, a research by Devi (2012) showed that there was no positive and significant influence on leadership styles toward turnover intention. Based on the previous researches' suggestion, this present study added perceived supervisor support toward employee's motivation to work and its impact on turnover intention.

According to the background described above, this study is focused on the Influence of Supervisor, Perceived Supervisor Support Toward Motivation and Its Impact on Turnover Intention of The Garment Employees" as the topic of the research. Specifically, the research questions of this research are as follows: 1) Does the supervisor leadership style affect the employee's motivation 2) Does the perceived supervisor support affect the employee's motivation 3) Does employee's motivation affect the turnover intention?

\section{LITERATURE REVIEW}

\section{Definition of Concept \\ Turnover Intention}

Turnover intention was defined as an employee's plan to leave their company. It is also called the desire to leave current the current job and intend to find a job or a new company. According Syahronica, Hakam \& Ruhana, (2015) turnover intention was a desire arising from the employee himself to leave the company immediately. Furthermore, Muliana (2013) stated that the turnover intention in question was the same as the intention to leave which was a desire or an intention from the employee himself to leave the current company he was working in by increasing the employee absence, starting to look lazy to work, and being less responsible toward his job. In a research by Listiniasih \& Mujiati (2015), the high level of the intention to leave could cause negative effect for the company, namely the increase of manpower cost.

There are several indicators of the turnover intention according to Chen and Francesco (in Dharma, 2013: 4) which are: 1) The intention to leave: an idea to leave the company which is based on several factors; 2) The desire to look for vacancies: where an individual is willing to look for another job or another company.

\section{Supervisor Leadership Style}

Leadership style was defined as an influence, motivation, or the ability of a leader too drive his subordinates to participate in order to reach the goals (Choi et al., 2012). According to Mongan, Lagarense, and Wowiling (2014), supervisor was the person who was in charge and responsible for managing and controlling the employee's work to be always in line with the company's plan. Thus, it 
can be interpreted that the supervisor leadership style is the attitude and actions a leader does in dealing with subordinates.

A supervisor must provide honest and open feedback to his subordinates. Supervisor leadership style is required to be such a professional role model in their field. According to Hersey and Blanchard (1996), leadership style is divided into several leadership styles, including:

\section{1) Instructional}

Instructional leadership style is a leader who demonstrates a behavior that gives a lot of direction or tasks but shows little support. The leader provides more specific and efficient instructions on the role and purpose of his subordinates.

\section{2) Consulting}

Consulting leadership style is a leader who demonstrates a behaviour that is leading and shows a lot of support. The leader is able to explain the decisions and policies taken and can accept opinions and communicate well.

\section{Perceived Supervisor Support}

The form of support from the supervisor can be seen through the perception of the employee, or also called perceived supervisor support. Supervisor support is shown when he assesses the subordinates' contribution as well as his concern for the subordinates (Ardianto, 2009). DeConninck \& Johnson, (2013) interpreted that the perceived supervisor support was the employees' belief and supervisor's concern toward and the employee's welfare.

Perceived supervisor support
can strengthen employee's expectations that the supervisor will provide sympathetic understanding and assistance to employees in the workplace. Supervisor support is basically something that the company's expectation for the employees. If they feel the support of supervisors and it is in accordance with the norms, wishes and expectations then the employees by themselves will fulfill their obligations to the company. Also, they will not have any desire to leave (Carl et al., 2007; DeConnick \& Johnson, 2013).

The indicator of the perceived supervisor support, according to Eisenberger, et al (2001), is supporting behaviour which is a behaviour performed by considering, receiving and caring for the needs and feelings of others. This treatment can help, build and maintain interpersonal relationships between a superior who cares and maintains good relationships with the employees. This can make the process of achieving better performance goals.

\section{Motivation}

In performing a job, it cannot be separated from the spirit and motivation from the employees, resulting them to work better. Motivation is a psychological process that reflects the interaction or attitudes, needs, perceptions and decisions experienced by a person. 
Motivation is the driver or activator within a person to act. Motivation to work is a condition that moves the employees directing them to achieve organizational goals. In this case, there is a positive relationship between achievement motives with performance achievement.

Without the motivation to work from the superiors or employees to work together for the company's business, the planned goals will not be achieved. Conversely, if there is a great motivation to work from superiors, then it is a guarantee for the success of the company in achieving its objectives. With the help of a good motivation from the supervisor, the employee turnover level will be lower.

The employees' motivation to work can be seen through how well they work is, how they work hard, and how they can produce better results. Employees actually have a diverse motivation, which is not only motivated by money (wages) or a desire for a satisfaction, but also the need for achievement and to have a meaning at work (Nugraheny, 2009). They also argued that some employees already had the drive within themselves and the supervisor's encouragement to complete the work well.

Hypothesis Development

The Influence of Supervisor Leadership Style Toward Motivation

Leadership style is an important factor to influence motivation to work. In a research by
Azhar (2009), it was found that leadership was related to motivation. Supervisor's leadership style had a strong influence to the employees' motivation, because the success of a leader in driving others to achieve a goal depends on how a leader can create the motivation to work in each employee. Employees' high motivation to work can be supported by having an appropriate supervisor leadership style Choi et al., 2012). In Benazir research (2013), supervisor leadership style was found to be very influential on employee's motivation, because in the employees' motivation to work to fulfil their need implies a need of a leader's support, hence every leader should know exactly what is needed by the employees in order to cooperate effectively.

Based on a number of previous studies (Riyadi, 2011, Benazir, 2013), they indicated that the leadership style significantly affected motivation to work. Thus, this study formulates the following hypothesis:

H1: Supervisor's leadership style has a significant effect on work motivation.

The Influence of Perceived Supervisor Support Toward Motivation to Work

The existence of high motivation to work from the supervisor is strongly influenced by the support from both in the social environment of the superior and colleagues. Employees have various motivations, which is not only the money or wages-oriented motivation 
or the desire for job satisfaction, but the supervisor support is also very influential on the employees' motivation (Nugraheny, 2009). Employees will develop perceptions related to their assessment. Employees will also develop their views to what extent supervisors judge, care, and motivate their employees.

This is happened because the supervisor acts as an organization responsible for his employees to provide motivation to work, direction and job evaluation toward the subordinates performance and the employees will also assess their supervisor's concern as a support from the organization.

Based on a previous research by Tatiyani (2004), the superior's support had a positive influence toward motivation. Besides, a study by Nugraheny (2009) also found that the superior's support had a positive effect on motivation to work. Thus, this study formulates the following hypothesis:

$\mathrm{H} 2$ : the perception of supervisor support has a positive effect on work motivation.

The Influence of Motivation Toward Turnover Intention

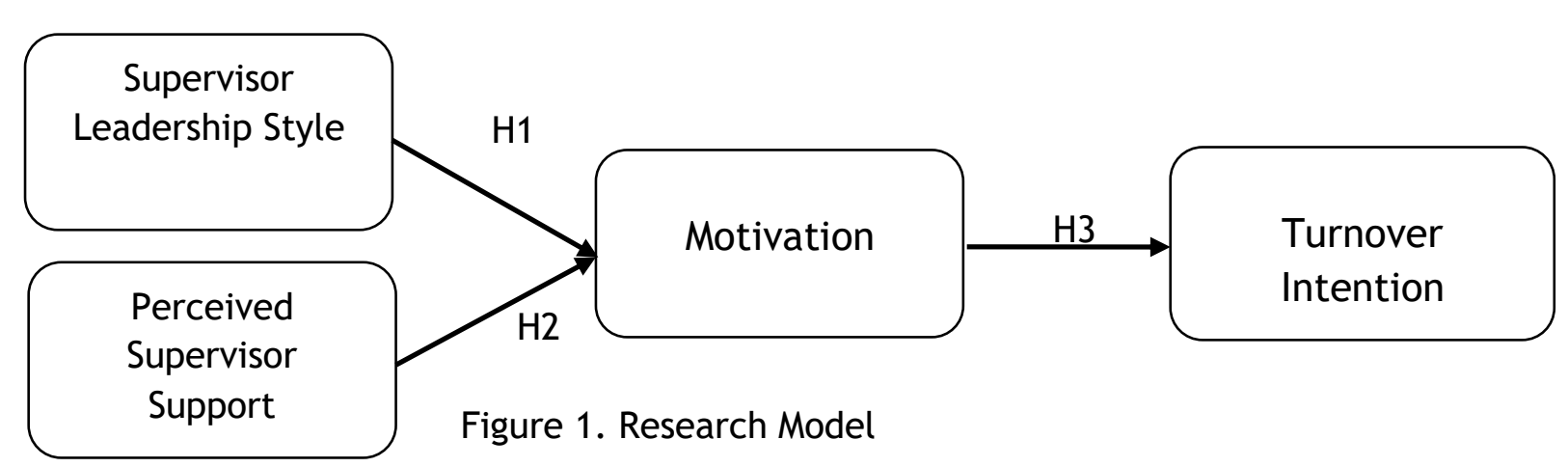

Motivation is fundamental to encourage employees towards the effort for more contribution for the company. As what has been widely known that motivation is a person's desire causing him to do a certain action. When a person is motivated, he will try to make his best to actualize what he wants (Trisiyanie, 2010). In a research by Putrianti, Hamid, and Mukzam (2014), it was found that there was a partially significant influence between motivation to work variables toward turnover intention. In addition, a research by Roni (2011) found that the motivation to work had a negative and significant impact on the employees' desire to leave.

Furthermore, a research by Trisiyanie (2010) also found that the motivation to work positively affected the desire to leave the company. Thus, this study formulates the following hypothesis:

H3: Work motivation negatively and significantly influence to Employee Turnover Intention.

\section{Research Model}

Therefore, based on the above description, a development model can be illustrated as follows. 


\section{Research Method}

The type of research conducted was a quantitative research, which aimed to examine some predefined hypotheses. The population of this research was the employees of production division of PT. Starlight Garment Bawen Semarang as many as 1057 employees. The sample determination of this research used non-random purposive sampling technique. It was taken using the Slovin formula as follows:

$$
n=\frac{N}{1+N e^{2}}
$$

Where $\mathrm{n}=$ number of samples, $\mathrm{N}=$ number of population and $\mathrm{e}=$ error tolerance limit (error tolerance $=0,05)$. Therefore, the based on the sample calculation, there were 290 samples.

In this study, questionnaires distributed were 300 questionnaires, yet the returned questionnaire were only 197 questionnaires and 25 questionnaires were not eligible or incomplete. Out of the total of 197 respondents, 134 respondents were female and 63 of them were male. Most of them aged between 18 years - 35 years $(87.82 \%)$ and the rest aged between $35-45$ years $(12.18 \%)$. As many as $39 \%$ of the respondents worked less than 2 years, 49\% worked between 2-5 years and $12 \%$ had worked in the company for over 5 years.

Data collection techniques in this study was done by distributing the questionnaires structurally to the employees of the production division at PT. Starlight Garment Bawen Semarang. The data was collected using Likert scale 1 5 , where 1 = strongly disagree, and 5 = strongly agree. The concept measurement used the existing scales, such as the concept of leadership style (Hersey and Blanchard, 1996); perceived supervisor support (Eisenberger, et al, 2001); motivation (Hasibuan, 2000; 156); turnover intention (Choi et al., 2012).

The analytical technique used in this study was done in a quantitative statistical descriptive analysis. Before testing the hypothesis, the reliability and validity tests were done. A validity test was considered valid if the value of $r$ count $>0.30$ (Ghozali, 2015). The data was said to be reliable if the value of cronbach coefficient alpha.> 0.6. Leadership (0.681, supervisor support: 0.965 , motivation $\quad(0.724) \quad$ Turnover intention $(0.823)$

The result of validity test of each variable such as supervisor leadership style, perceived supervisor support, motivation and turnover intention obtained ItemTotal Correlation value of each indicator to be greater than 0,3 which indicated that the data was valid and could be analyzed further (Ghozali, 2005). The reliability test results based on Cronbach Alpha (a) values indicated that from each variable such as of supervisor leadership style, perceived supervisor support, motivation and turnover intention fulfilled the reliability element with Cronbach Alpha (a) values to be greater than 
0.60 (Ghozali, 2005). Thus, all indicators of supervisor leadership style, supervisor support perceptions, motivation and turnover intention variables could be used for further data processing.

\section{FINDINGS AND DISCUSSION}

The following table presents

the descriptive statistics of

supervisor leadership style,
perceived supervisor support,
motivation and turnover intention
variable. From the table, it can be
explained that the highest average
value of the supervisor leadership
style dimension is the instructional
as much as 4.34 .

supervisor leadership style, perceived supervisor support, motivation and turnover intention

Table 1. Descriptive Statistics of Supervisor Leadership Style

\begin{tabular}{|c|c|c|c|}
\hline No & Supervisor Leadership Style & Average & Explanation \\
\hline \multicolumn{4}{|c|}{ A. Intructional } \\
\hline 1 & $\begin{array}{l}\text { Supervisors always give clear instructions to the } \\
\text { subordinates. }\end{array}$ & 4.40 & High \\
\hline 2 & $\begin{array}{l}\text { Supervisor always explain the tasks that must be } \\
\text { done }\end{array}$ & 4.35 & Very High \\
\hline 3 & $\begin{array}{l}\text { Supervisors always provide direction to work } \\
\text { effectively and efficiently. }\end{array}$ & 4.26 & Very High \\
\hline & Average & 4.34 & Very High \\
\hline \multicolumn{4}{|c|}{ B. Consulting } \\
\hline 4 & $\begin{array}{l}\text { Supervisors always give the subordinates an } \\
\text { opportunity to discuss issues with the superior. }\end{array}$ & 4.19 & High \\
\hline 5 & $\begin{array}{l}\text { Supervisors always give the subordinates an } \\
\text { opportunity to convey their feelings and concerns. }\end{array}$ & 4.04 & High \\
\hline 6 & $\begin{array}{l}\text { Supervisors always communicate well with the } \\
\text { subordinates. }\end{array}$ & 4.07 & High \\
\hline & Average & 4.10 & High \\
\hline
\end{tabular}

Source: processed primary data, 2018

instructions to the subordinates as

An indicator which shows to be much as 4.40 and when the above the average is when the supervisor always gives clear supervisor always explain the tasks that must be done as much as 4.35 .

Table 2. Descriptive Statistics of Perceived Supervisor Support

\begin{tabular}{clcc}
\hline No & \multicolumn{1}{c}{ Perceived Supervisor Support } & Average & Explanation \\
\hline \begin{tabular}{c} 
A. Supporting behavior \\
\hline 1
\end{tabular} & $\begin{array}{l}\text { Supervisors are genuinely concerned with the } \\
\text { employees' welfare. }\end{array}$ & 4.13 & High \\
\hline 2 & $\begin{array}{l}\text { Supervisors pay attention to personal goals and } \\
\text { values. }\end{array}$ & 4.19 & High \\
\hline 3 & $\begin{array}{l}\text { Supervisors pay attention to my overall job } \\
\text { satisfaction. }\end{array}$ & 4.11 & High \\
\hline 4 & $\begin{array}{l}\text { Supervisors are willing to assist employees when } \\
\text { employees need special help. }\end{array}$ & 4.07 & High \\
\hline
\end{tabular}




\begin{tabular}{lllll}
\hline 5 & $\begin{array}{l}\text { If the employee decides to stop working or leave } \\
\text { the company, the boss tries to persuade her to stay. }\end{array}$ & 4.03 & High \\
\hline 6 & $\begin{array}{l}\text { Supervisors provide positive support so that } \\
\text { employees are able to show their best performance. }\end{array}$ & 3.62 & High \\
\hline Average & 4.02 & High \\
\hline
\end{tabular}

Source: processed primary data, 2018

The perceived supervisor support with an indicator score to be above the average is when the supervisor takes into account personal goals and values which scores as much as 4,198, then when the supervisor is really concerned with the employee's welfare for 4,123 , when the supervisor is paying attention to the overall job satisfaction for 4,112, when the supervisor is willing to help when the employee requires special help for 4,071 . While the lowest indicator is shown when the supervisor gives positive support to employees so that employees are able to show the best performance for 3.624 .

Table 3. Descriptive Statistics of Motivation

\begin{tabular}{clcc}
\hline \multicolumn{1}{c}{ No } & \multicolumn{1}{c}{ Motivation } & Average & Explanation \\
\hline A. & Implementation Success & 4.20 & High \\
\hline 1 & Always excited about doing the work. & 4.11 & High \\
\hline 2 & Always try and focus on doing the work. & 4.07 & High \\
\hline 3 & $\begin{array}{l}\text { Always work with full calculation to get the job } \\
\text { done based on the goals. }\end{array}$ & 4.13 & High \\
\hline$\quad$ Rata-rata & & High \\
\hline B. Responsibility & 3.75 & High \\
\hline $4 \quad \begin{array}{l}\text { I am willing and responsible for additional hours of } \\
\text { work given at work. }\end{array}$ & 3.91 & High \\
\hline 5 & $\begin{array}{l}\text { Always strive to make my work productivity more } \\
\text { than my coworkers }\end{array}$ & 3.76 & High \\
\hline 6 & Always reach the target at work. & 3.81 & High \\
\hline & Average & 3.97 & \\
\hline & Total Average &
\end{tabular}

The implementation success is the highest dimension of motivation as much as 4.134 which means that there was a spirit from the employees in doing the job, the employees always tried and focuses in doing the job and the employees always worked with full calculation to get the job done based on the goals.

Table 4. Descriptive Statistics of Turnover Intention

\begin{tabular}{clcc}
\hline No & \multicolumn{1}{c}{ Turnover Intention } & Average & Explanation \\
\hline \multicolumn{1}{c}{ A. } & The intention to leave & & \\
\hline 1 & $\begin{array}{l}\text { Intended to leave the company because my job is } \\
\text { too heavy. }\end{array}$ & 2.65 & Fair \\
& & & \\
\end{tabular}




\begin{tabular}{clcc}
\hline 2 & Often thinking about quitting work right away. & 2.53 & Low \\
\hline 3 & $\begin{array}{l}\text { Intended to leave because other companies have } \\
\text { decent jobs. }\end{array}$ & 2.55 & Low \\
\hline & Average & 2.57 & Low \\
\hline B. & The desire to seek vacancies & & \\
\hline 4 & Thinking of finding a new job. & 2.31 & Low \\
\hline 5 & $\begin{array}{l}\text { Looking for information about job vacancies } \\
\text { somewhere. }\end{array}$ & 2.27 & Low \\
\hline & Average & 2.29 & Low \\
\hline & Total average & 2.46 & Low \\
\hline
\end{tabular}

Examining Hypotheses

Hypothesis 1: The Influence of

Supervisor Leadership Style
Supervisor and Perceieved

Supervisor Support Toward

Motivation

\begin{tabular}{lcccc}
\hline \multicolumn{4}{c}{ Model Summary } \\
\hline Model & $\mathrm{R}$ & R Square & $\begin{array}{c}\text { Adjusted R } \\
\text { Square }\end{array}$ & $\begin{array}{c}\text { Std. Error of } \\
\text { the Estimate }\end{array}$ \\
\hline 1 & $.235^{\mathrm{a}}$ & .455 & .470 & 2.402 \\
\hline $\begin{array}{l}\text { a. Predictors: (Constant), Perceived Supervisor Support, Supervisor } \\
\text { Leadership Style }\end{array}$ & & & \\
\hline
\end{tabular}

Adjusted $\mathrm{R}$ Square value is 0.470 so the variations of motivation variables influenced by supervisor leadership style and perceived supervisor support is $47 \%$ and the remaining $53 \%$ is influenced by other variables outside the research model.

To test the hypothesis of the influence of the supervisor leadership style and the perceived supervisor support toward motivation, the result is as follows.

The coefficient numbers in the equation show that there is a positive influence between the supervisor leadership style and the perceived supervisor support toward motivation. So, if the better the supervisor leadership style and the perceived supervisor support, the more increased the motivation is.

\begin{tabular}{|c|c|c|c|c|c|c|}
\hline \multicolumn{7}{|c|}{ Coefficients $^{\mathrm{a}}$} \\
\hline \multirow[t]{2}{*}{ Model } & & \multicolumn{2}{|c|}{ Unstand.Coef } & \multirow{2}{*}{$\begin{array}{c}\text { Stand Coef. } \\
\text { Beta }\end{array}$} & \multirow[t]{2}{*}{$\mathrm{t}$} & \multirow[t]{2}{*}{ Sig. } \\
\hline & & B & $\begin{array}{l}\text { Std. } \\
\text { Error }\end{array}$ & & & \\
\hline \multirow[t]{3}{*}{1} & (Constant) & 13.706 & 3.262 & & 4.202 & .000 \\
\hline & $\begin{array}{l}\text { Supervisor Leadership } \\
\text { Style }\end{array}$ & .314 & .092 & .340 & 2.848 & .007 \\
\hline & $\begin{array}{l}\text { Perceived Supervisor } \\
\text { Support }\end{array}$ & .334 & .081 & .377 & 3.056 & .003 \\
\hline
\end{tabular}


a. Dependent Variable: Motivation

Partially, the supervisor leadership style variable and the perceived supervisor support influence the motivation shown by the significance value of 0.007 and 0.007 which is smaller than 0.05 .

\begin{tabular}{llrrccc}
\hline \multicolumn{7}{c}{ ANOVA $^{\mathrm{b}}$} \\
\hline Model & & Sum of Squares & Df & Mean Square & F & \multicolumn{1}{c}{ Sig. } \\
\hline 1. & Regression & 65.296 & 2 & 32.648 & 5.658 & $.004^{\mathrm{a}}$ \\
\cline { 2 - 8 } & Residual & 1119.506 & 194 & 5.771 & & \\
\cline { 2 - 7 } & Total & 1184.802 & 196 & & & \\
\hline
\end{tabular}

aPredictors: (Constant), Perceived Supervisor Support, Supervisor Leadership Style

b. Dependent Variable: Motivations

Simultaneously, supervisor leadership style and perceived supervisor support variable both affect the motivation shown with a significance value of 0.004 which is smaller than 0.05 .

Hypothesis 2: The Impact of Motivation Toward Turnover Intention
To examine the hypothesis of the impact of motivation toward turnover intention is as follows:

$\mathrm{R}$ Square value is 0.374 , so the variation of intention turnover influenced by motivation is $37.40 \%$ and the rest $62.60 \%$ is influenced by other variables outside the research model.

\begin{tabular}{|c|c|c|c|c|}
\hline \multicolumn{5}{|c|}{ Model Summaryb } \\
\hline Model & $\mathrm{R}$ & R Square & $\begin{array}{c}\text { Adjusted R } \\
\text { Square }\end{array}$ & $\begin{array}{l}\text { Std. Error of } \\
\text { the Estimate }\end{array}$ \\
\hline 1 & $.411^{a}$ & .369 & .374 & 3.528 \\
\hline
\end{tabular}

\begin{tabular}{|c|c|c|c|c|c|c|}
\hline \multicolumn{7}{|c|}{ Coefficients $^{a}$} \\
\hline \multirow[t]{2}{*}{ Model } & & \multicolumn{2}{|c|}{$\begin{array}{l}\text { Unstandardized } \\
\text { Coefficients }\end{array}$} & \multirow{2}{*}{$\begin{array}{c}\text { Standardized } \\
\text { Coefficients } \\
\text { Beta }\end{array}$} & \multirow[t]{2}{*}{$T$} & \multirow[t]{2}{*}{ Sig. } \\
\hline & & B & Std. Error & & & \\
\hline \multirow[t]{2}{*}{1} & (Constant) & 27.706 & 2.456 & & 11.280 & .000 \\
\hline & Motivation & -.645 & .102 & -.411 & -6.298 & .000 \\
\hline
\end{tabular}

a. Dependent Variable: Turnover Intention

The coefficient numbers in the equation show that there is a negative influence between motivation toward turnover intention. So, if the better the motivation, the more reduced the turnover intention is. Partially, the motivation variable influence the turnover intention which is indicated 
by the significance value of 0.000 which is smaller than 0.05 .

Discussion

Supervisor leadership style had a positive influence toward motivation. This result was in line with studies by Riyadi (2011) and Benazir (2013) which showed that supervisor leadership style positively influenced employees' motivation to work. This indicated that the better the supervisor leadership style in the garment industry, the more increased the employee's motivation in the garment industry would be. This result was supported by the opinion of respondents that the supervisor leadership style in PT. Starlight Garment was an instructional leadership style where supervisors always gave clear instructions to the subordinates and supervisor always explained the tasks that must be done. The employees' high motivation could be supported by the supervisor leadership style or the appropriate supervisor, so that the application of inappropriate leadership style would less motivate subordinates in doing their job.

The perceived supervisor support positively influenced the motivation. The result of this research was in line with a research by Tatiyani (2004) and DeConninck \& Johnson (2013) which proved that the superiors' support had a positive influence toward motivation. This indicated that the better the supervisor support, the more increased the employee's motivation at PT. Starlight Garment. This result was supported by a respondent's opinion based on descriptive statistic that the supervisor was really concerned with employee's welfare, supervisor paid attention to overall job satisfaction, supervisor was willing to help when he/she needed special help and if any employee decided to stop working or leaving the company, the boss would try to convince to stay in the company.

$$
\text { Motivation negatively }
$$

affected turnover intention. The results of this study were in line with a research by Trisiyanie (2010) and Jandu (2015) who found a negative influence between motivation toward turnover intention. This indicated that the higher the motivation of employees in PT. Starlight Garment, the more reduced the employees' turnover intention level at PT. Starlight Garment. A phenomenon where the employees decided not to look for another job was happened because it was in accordance with the opinions of respondents saying that the employees were motivated they had a spirit in doing their job, that they always tried and focused in doing their job and that the employee always worked with full calculation in order to complete the work based on the goals. Motivation was fundamental to encourage employees in the garment industry to have more contribution for the company. As what has been widely known that motivation is a person's desire causing him to do a certain action. When a person is motivated, he will try to make his best to actualize what he wants. By having a high motivation to work in the 
garment employees, the employee turnover would be lower.

\section{CONCLUSION AND IMPLICATION}

\section{Conclusion}

1. Supervisor leadership style had a positive effect toward motivation. This indicated that the better the supervisor leadership style in the garment industry, the more increased the employee's motivation in the garment industry would be in PT. Starlight Garment.

2. Perceived supervisor support positively influenced motivation. This indicated that the better the supervisor support, the more increased the employee's motivation at PT. Starlight Garment.

3. Motivation negatively affected turnover intention This indicated that the higher the motivation of employees in PT. Starlight Garment, the more reduced the employees' turnover intention level at PT. Starlight Garment.

\section{Theoretical Implication}

Supervisor leadership style and perceived supervisor support had a positive effect toward motivation. This result was in line with the research by Riyadi (2011) and Benazir (2013) which indicating that supervisor leadership style and perceived supervisor support had a positive effect toward employees' motivation to work. Motivation negatively affected turnover intention. The result of this study was in line with the research by Trisiyanie (2010) and Jandu (2015) who found a negative influence between motivation toward turnover intention.

Limitation and Suggestion for future research

Respondents in this study consisted of female and male workers (32\%). In fact, in the majority of garment workers in the production section are women. Thus the results of this study are expected to be interpreted more carefully, especially related to the variable perceived supervisor support.

Future research is recommended to retest this model for female workers only. And analysis should also be related to demographic characteristics such as education level, age, years of service, and marital status. This research model can also be tested in the population of male worker respondents, who might give different research results to enrich this field of research.

\section{REFERENCE}

Ardianto, A. (2009). Perceived Organizational Support Sebagai Pemediasi Pengaruh Keadilan Prosedural, Penghargaan, Dan Dukungan Supervisor Terhadap Komitmen Afektif (Unpublished Thesis, Sebelas Maret University, Surakarta, Indonesia).

Azhar, F. (2009). Hubungan Antara Gaya Kepemimpinan dengan Motivasi Kerja Karyawan dalam Organisasi Perusahaan 
(Unpublished Thesis, IPB University, Bogor, Indonesia).

Benazir, N.A. (2013). Hubungan Gaya Kepemimpinan Dengan Motivasi Kerja Pegawai Pada Dinas Pendidikan Provinsi Jawa Barat (Unpublished Thesis, Widyatama University, Bandung, Indonesia).

Curiel, T. J., et al. (2004). Specific recruitment of regulatory $t$ cells in ovarian carcinoma fosters immune privilege and predicts reduced survival. Nature Medicine, 10, 942-949.

DeConinck, J.B., \& Johnson, J.T. (2013). The Effects of Perceived Supervisor Support, Perceived Organizational Support, and Organizational Justice on Turnover among Salespeople. Journal of Personal Selling \& Sales Management, 29(1), 333-350. https://doi.org/10.2753/PSS08 85-3134290403

Dharma, C. (2013). Hubungan antara turnover intention dengan komitmen organisasional di PT. $\mathrm{X}$ medan. Jurnal Ekonomi dan Bisnis Jurusan Administrasi Niaga Politeknik Negeri Medan, 1(2), 1-9.

Eisenberger, R., Armeli, S., Rexwinkel, B., Lynch, P.D., \& Rhoades, L. (2001). Reciprocation of perceived organizational support. Journal of Applied Psychology, 86(1), 42-51.
Gandika, I., \& Fransiska, R. (2015). Pengaruh Kepuasan Kerja Terhadap Turnover Intention dengan Karakteristik Sosial Demografi sebagai Variabel Moderator (Studi Kasus pada PT. Strarlight Garment Semarang. Proccedings of the $4^{\text {th }}$ Economic \& Business Research Festival (pp. 655669). Salatiga, Indonesia.

Ghozali, I. (2005). Aplikasi Analisis Multivariate dengan Program IBM SPSS 19. Semarang, Indonesia: Badan Penerbit UNDIP.

Hersey, P., \& Blanchard, K.H. (1996). Manajemen perilaku organisasi, pendayagunaan Sumber Daya Manusia. Jakarta, Indonesia: Erlangga .

Jandu, M. (2015). Analisis pengaruh keterlibatan kerja motivasi kompensasi dan gaya kepemimpinan terhadap turnover intention, studi pada PT. Zenith Allmart Precisindo Sidoarjo. Jurnal Universitas Narotama.

Paaisal, L. O. R., Tabroni, T., \& Maksum, C. (2018). Pengaruh Gaya Kepemimpinan dan Budaya Organisasi Terhadap Turnover melalui Kepuasan Kerja Karyawan Pada PT. Muara Wisesa Samudra Di Jakarta. Jurnal Eksekutif, 15(1).

Listiniasih, N. P. D., \& Mujiati, N. W. (2015). Pengaruh kepuasan kerja dan komitmen organisasi 
terhadap keinginan keluar pada Bali Nature Land Tour, Tabanan. Jurnal Fakultas Ekonomi dan Bisnis, 4(3), 500525.

Maertz, C.P., Griffeth, R.W., Campbell, N.S., \& Allen, D.G. (2007). The effects of perceived organizational support and perceived supervisor support on employee turnover. Journal Organization Behavior, 28(8), 1059-1075.

https://doi.org/10.1002/job.4

$\underline{72}$

Mongan, Lagarense, B.E.S., \& Wowiling, R.A.J. (2014). Analisis kepemimpinan supervisor dalam meningkatkan kinerja karyawan $f \& b$ service hotel. Jurnal Hospitaliti dan Pariwisata, 1(2), 2354-8355.

Muliana, S. (2013). Faktor-Faktor yang Mempengaruhi Keinginan Pindah Kerja Perawat Rumah Sakit Atma Jaya. (Unpublished Thesis, Esa Unggul University, Tangerang, Indonesia).

Nugraheny, P.S. (2009). Analisis Pengaruh Kepuasan Kerja, Dukungan Organisasi, Dan Gaya Kepemimpinan Terhadap Motivasi Kerja Dalam Meningkatkan Kinerja Karyawan. (Unpublished Thesis, Diponegoro University, Semarang, Indonesia).
Putrianti, A.D., Hamid, D., \& Mukzam, M.D. (2014). Pengaruh kompensasi dan, motivasi kerja terhadap turnover intention. Jurnal Administrasi Bisnis, 12(2), 1-9.

Riyadi, S. (2011). Pengaruh Kompensasi Finansial, Gaya Kepemimpinan, dan Motivasi Kerja Terhadap Kinerja Karyawan pada Perusahaan Manufaktur di Jawa Timur. Jurnal Manajemen Dan Kewirausahaan, 13(1), 40-45.

Roni, S. A. (2011). Pengaruh gaya kepemimpinan, motivasi, kompensasi, dan kepuasan kerja terhadap keinginan berpindah karyawan PT. Garudafood Putra Putri Jaya Pati. Jurnal Fakultas Ekonomi dan Bisnis.

Sidharta, N., \& Margaretha, M. (2011). Dampak komitmen organisasi dan kepuasan kerja terhadap turnover intention: studi empiris pada karyawan bagian operator di salah satu perusahaan garment di Cimahi. Jurnal Manajemen, 10(2), 129142.

Trisiyanie, N. (2010). Pengaruh Kompensasi, Motivasi Dan Kepuasan Kerja Terhadap Keinginan Untuk Keluar. (Unpublished Thesis, Pembangunan Nasional "Veteran" University, Indonesia). 